\title{
La radiografer beskrive røntgenbilder!
}

\author{
Bildediagnostiske undersøkelser etterspørres mer enn noen gang. Avdelingene sliter med opphopning \\ av bildeundersøkelser som ikke er beskrevet, samtidig som det er mangel på radiologer. Vi foreslår å la \\ videreutdannede radiografer beskrive utvalgte røntgenbilder.
}

Det pågår en heftig diskusjon i det norske radiologiske miljøet. Uenigheten gjelder radiografers rolle og hvorvidt de kan, og bør, vurdere og beskrive bildediagnostiske undersøkelser. Så langt har radiografene sørget for pasienthåndtering og bildeopptak, mens det diagnostiske arbeidet med tyding og resultatformidling har vært legearbeid utført av radiologer.

Særlig i England og Danmark har man forsøkt å bøte på radiologmangelen ved å videreutdanne radiografer slik at de kan tyde og beskrive utvalgte undersøkelser. Norsk radiografforbund har omfavnet ideen og ser gjerne en lignende utvikling her til lands (1). Slik rolleutvidelse gir radiografene nye karrieremuligheter og passer utvilsomt godt inn i bildet av en bevisst helseprofesjon som beveger seg i stadig mer akademisk retning.

Tre høgskoler i Sør-Norge, alle med radiografutdanninger, vil nå samarbeide om en videreutdanning til beskrivende radiograf innen skjelettrøntgen (2). Planen er opptak av første studentkull høsten 2016. Utdanningen skal være et deltidsstudium, der mye av læringen skjer ute ved de radiologiske avdelingene. Ferdigheter skal tilegnes gjennom praktiske øvelser der radiologer er ønsket som veiledere og kunnskapsformidlere.

Dette sier Norsk radiologisk forening bastant nei til. De ønsker ikke å legitimere et slikt studium ved å delta i planlegging og faglig utforming. Foreningens styre går så langt at de i en nylig distribuert uttalelse fraråder sine medlemmer å bidra i undervisning, veiledning eller mentorvirksomhet knyttet til utdanning av beskrivende radiografer (3).

\section{Gode erfaringer \\ fra Sykehuset i Vestfold}

Erfaringene med beskrivende radiografer er i Norge begrensede, og det er lite tilgjengelig dokumentasjon rundt nytte og effekt. Det er imidlertid synd at denne profesjonsstriden hardner til før man får anledning til å utforske de muligheter, men også begrensninger, som ligger i denne formen for jobbglidning.

Ved Sykehuset i Vestfold har vi en beskrivende radiograf i funksjon innen fagfeltet skjelettrøntgen, og ved Radiologisk avdeling er vi så langt svært fornøyd med ordningen. Utdanningen, som ble støttet økonomisk av sykehuset, besto av teoretisk universitetsstudium i England kombinert med praktiske øvelser i egen avdeling der to av avdelingens radiologer fungerte som mentorer. Etter bestått eksamen fortsatte vi en tid med organisert veiledning hvor svar ble kontrasignert av overlege. Etter samlet to og et halvt år har beskrivende radiograf fått myndighet til selv å signere ut egne røntgensvar på lik linje med avdelingens overleger. Beskrivende radiograf jobber imidlertid alltid i et granskningsmiljø med leger til stede for spørsmål og diskusjon.

Vi har investert mye, både faglig og økonomisk i utdanning og opplæring, men allerede nå gir dette betydelig tilbake. Minst like viktig som avlastning av avdelingens

\section{«Det er ingen som bør føle seg truet av radio- grafer i utvidede roller»}

leger, er rollen som brobygger mellom radiografgruppen og det diagnostiske miljøet blant radiologene. Beskrivende radiograf har innsikt $\mathrm{i}$ det radiograffaglige håndverket og hvordan gode og riktige skjelettbilder er avgjørende for riktig diagnose. Hun jobber aktivt inn mot de øvrige radiografene med undervisning og organisert individuell veiledning med bedret bildekvalitet som resultat. Tilsvarende formidler hun oppmerksomhet og kunnskap til radiologene, både leger i spesialisering og overleger, om betydningen av riktige bilder og projeksjoner. Prosessen med beskrivende radiograf har i vår avdeling vitalisert et fagområde som lett får lav prioritet. Avdelingen har fått en dedikert person med stor teoretisk kunnskap innen feltet som utfordrer og stimulerer til økt kvalitet i alle ledd.

Vi har gitt oss god tid både i planlegging og oppbyggingsfase. Dette er nybrottsarbeid som ikke må forseres. Det har vært bred enighet om satsingen blant avdelingens radiologer, og vi har ingen betenkeligheter med å anbefale andre radiologiske avdelinger å gå inn på lignende opplegg.

\section{Begrav profesjonsøksen!}

Vi beklager det som nå skjer rundt oppstart av et norsk utdanningsprogram for beskrivende radiografer. På den ene siden mener vi studiet kommer for raskt. Det radiologiske miljøet er ikke modent for dette. Erfaringsgrunnlaget er for lite, usikkerheten og skepsisen for stor. Etter vår mening vil vi være bedre tjent med piloter der radiografer sendes til etablerte utdanningssteder i utlan- det. Det vil ta tid å utvikle en rolleforståelse for beskrivende radiograf, og ordningen må vurderes og evalueres systematisk. På den andre siden er vi forundret over radiologforeningens steile og negative holdning, som av utenforstående lett kan oppfattes som konservativ og proteksjonistisk. Her er vi alle i samme båt, og foreningen burde kunne bidra på en langt mer konstruktiv måte. Det er ingen som bør føle seg truet av radiografer i utvidede roller. Heller bør man se muligheter for gode fagteam i de radiologiske avdelingene, der både kapasitet og kvalitet kan utvikles parallelt. Beskrivende radiografer løser alene ikke kapasitetsproblemet for radiologiske tjenester, men vi mener det er et skritt i riktig retning, også når det gjelder kvalitet.

Og hva med pasientene oppi alt dette? Pasientene ønsker gode bildediagnostiske tjenester til rett tid. Det er resultatene som teller. Personalets titler bryr nok de færreste seg om.

\section{Einar Vigeland \\ einar.vigeland@siv.no \\ Anders M. Hager}

Einar Vigeland (f. 1961) er spesialist i radiologi og overlege ved Radiologisk avdeling, Sykehuset i Vestfold.

Forfatter har fylt ut ICMJE-skjemaet og oppgir ingen interessekonflikter.

Anders Mikael Hager (f. 1969) er spesialist i radiologi og konstituert avdelingssjef ved Radiologisk avdeling, Sykehuset i Vestfold. Forfatter har fylt ut ICMJE-skjemaet og oppgir ingen interessekonflikter.

\section{Litteratur \\ 1. Norsk radiografforbund. Profesjonspolitikk. www.radiograf.no/meningerogpolitikk/Sider/ Profesjonspolitikk.aspx (5.3.2016). \\ 2. Høgskolen i Oslo og Akershus. Programplan for videreutdanning av radiografer - tolkning og beskrivelse av skjelettrøntgenbilder. www.hioa.no/ Studies/HF/Evu/Tolking-og-beskrivelse-av- skjelettroentgenbilder/Programplan-for- Videreutdanning-for-radiografer-tolking-og- beskrivelse-av-skjelettroentgenbilder-kull-2016 (5.3.2016). \\ 3. Norsk radiologisk forening. Beskrivende radio- grafer. http://legeforeningen.no/Fagmed/Norsk- radiologisk-forening/Nyheter/Foreningsstoff/} Beskrivende-radiografer/ (5.3.2016).

Mottatt 1.3. 2016, første revisjon innsendt 7.3. 2016 , godkjent 10.3. 2016. Redaktør: Ketil Slagstad.

Publisert først på nett. 